\title{
Australian abalone (Haliotis laevigata, H. rubra and $H$. conicopora) are susceptible to infection by multiple abalone herpesvirus genotypes
}

\author{
Serge Corbeil* , Lynette M. Williams, Kenneth A. McColl, Mark St. J. Crane \\ CSIRO Health and Biosecurity, Australian Animal Health Laboratory, 5 Portarlington Road, Geelong East, Victoria 3220, \\ Australia
}

\begin{abstract}
From 2006 to 2012, acute mortalities occurred in farmed and wild abalone (Haliotis spp.) along the coast of Victoria, Australia. The disease (abalone viral ganglioneuritis; AVG) is associated with infection by an abalone herpesvirus (AbHV). The relative pathogenicity of 5 known variants of AbHV was evaluated on abalone stocks from different states in Australia. Results indicated that all virus variants (Vic1, Tas1, Tas2, Tas3 and Tas4) cause disease and mortality in all abalone stocks tested (greenlip, blacklip and brownlip). In order to avoid further AVG outbreaks in Australian wild abalone, strict regulations on the transfer of abalone stocks must be implemented.
\end{abstract}

KEY WORDS: Abalone viral ganglioneuritis · AVG $\cdot$ Abalone herpesvirus $\cdot$ AbHV $\cdot$ Experimental challenge $\cdot$ Susceptibility to AVG

\section{INTRODUCTION}

Abalone viral ganglioneuritis (AVG), an acute disease associated with very high mortality (up to $100 \%$ ), was first observed in abalone Haliotis laevigata land-based farms in Victoria, Australia (Hooper et al. 2007). Histopathological and electron microscopic analyses of neural tissues (Tan et al. 2008), as well as subsequent genomic sequencing of purified virus (Savin et al. 2010) revealed the aetiological agent to be a herpesvirus, now designated abalone herpesvirus (AbHV). AVG is characterized by inflammation and necrosis of the nervous tissues of affected abalone (Hooper et al. 2007, Corbeil et al. 2012). Soon after its emergence on farms, AbHV was found in wild abalone, causing significant economic losses to the wild-capture industry in Victoria. This prompted the urgent development of molecular diagnostic assays for the detection of AbHV in order to help industry and regulatory authorities to manage the disease (Corbeil et al. 2010). In 2008, the virus was discovered in a processing plant in Tasmania,

\footnotetext{
*Corresponding author: serge.corbeil@csiro.au
}

and similar occurrences were observed annually from 2009 to 2012 (Ellard et al. 2012). Partial sequencing of all Tasmanian virus variants showed nucleotide variations in some genes (Cowley et al. 2012); however, it is not known whether these variations would have an effect on their pathogenicity. In addition, unlike Victoria, no disease outbreak was seen in Tasmanian wild Haliotis populations.

Abalone species such as $H$. diversicolor Reeve in China (Wang et al. 2004) and H. diversicolor supertexta (Chang et al. 2005) have also suffered herpesvirus infections, but no information is available on the diversity of viral strains involved. Similarly, in Australia, no study has been conducted to establish whether all Australian abalone species/stocks are susceptible to infection with AbHV, and whether AVG is the inevitable outcome of infection.

Crane et al. (2013) showed that surviving abalone from wild populations that had previously undergone AVG outbreaks had not developed resistance to the disease. It is not known whether all recognized variants of AbHV would have the same impact on Aus-

() The authors 2016. Open Access under Creative Commons by Attribution Licence. Use, distribution and reproduction are unrestricted. Authors and original publication must be credited. 
tralian abalone stocks. Therefore, in order to better understand the epidemiology of AbHV and its potential effect on abalone stocks around Australia, laboratory challenge trials were performed using 5 genetically different variants of $\mathrm{AbHV}$ and the predominant abalone species from the temperate waters in the states of Tasmania, Victoria, South Australia (SA) and Western Australia (WA). Susceptibility was evaluated based on the presence or absence of virus DNA in abalone tissue and survival rate upon viral challenge.

\section{MATERIALS AND METHODS}

\section{Origin and species of abalone}

Healthy control abalone, blacklip Haliotis rubra $\times$ greenlip $H$. laevigata hybrids (approximately $70 \mathrm{~mm}$ in length and 2 yr old), were obtained from the Craig Mostyn Group, Jade Tiger abalone Pty Ltd, Indented Head, Victoria, where there has been no history of AVG. In addition, abalone samples from this farm have consistently tested negative using the AbHVspecific qPCR test (ORF-49 and ORF-66 qPCR; Corbeil et al. 2010, OIE 2015). These abalone were used as positive controls as well as to produce water containing infectious virus of each variant for the immersion challenge trials. The experimental abalone were blacklip, greenlip and brownlip $H$. conicopora obtained from the following suppliers: 888 Abalone Pty Ltd, WA (greenlip and brownlip; $\sim 70 \mathrm{~mm}$ in length, $\sim 3$ yr old), Costal Seafarms Pty Ltd, Victoria (greenlip $\sim 70 \mathrm{~mm}, \sim 3 \mathrm{yr}$; this stock of abalone originated from SA); Ocean Wave Seafoods Pty Ltd, Victoria (greenlip and blacklip; $30 \mathrm{~mm}, \sim 2 \mathrm{yr}$ and $65 \mathrm{~mm}, \sim 3 \mathrm{yr}$, respectively); and Abtas Marketing Pty Ltd, Tasmania (greenlip and blacklip; $~ 80 \mathrm{~mm}, \sim 4 \mathrm{yr}$ old).

To allow the experimental abalone to acclimate to the laboratory, they were placed for 4 to $5 \mathrm{~d}$ in individual tanks containing aerated, filtered, natural seawater maintained at $16-18^{\circ} \mathrm{C}$, and fed small food pellets daily (Halo; Skretting). During experiments, all tanks underwent a 100\% water change every $2 \mathrm{~d}$. Abalone were sampled for laboratory analysis when they showed signs of morbidity (e.g. lethargy and inability to attach to the substrate).

\section{Preparation of infectious water}

The Victorian variant Vic1 and the Tasmanian variants Tas1, 2, 3 and 4 of AbHV were used in this study.
Viral stocks were prepared according to the methodology described previously (Corbeil et al. 2012). Four days (Vic1, Tas1, 3 and 4) and $5 \mathrm{~d}$ (Tas2) prior to immersion challenge, 15 abalone were injected intramuscularly with $0.1 \mathrm{ml}$ of a 1:100 dilution of the previously prepared viral stock and then maintained in 201 of aerated seawater at $16-18^{\circ} \mathrm{C}$. Water was changed daily, and on Days 4 or 5 post-injection (determined by the specific viral variant) the infectious water from the tank was collected and diluted in seawater at 1:2 for the immersion challenges.

\section{Immersion challenge}

Eight abalone per species were challenged by immersion in $1 \mathrm{l}$ individual tanks of seawater for $20 \mathrm{~h}$. All groups of abalone species in any given experiment were exposed to an identical viral challenge dose (1:2 dilution). The negative control group consisted of 8 abalone immersed in seawater free of virus in a separate room. After the $20 \mathrm{~h}$ exposure period, the challenge water was removed and fresh seawater $\left(16-18^{\circ} \mathrm{C}\right)$ was added to each tank and changed every $2 \mathrm{~d}$. Animals were monitored daily for signs of morbidity. Based on reports from natural disease outbreaks and previous experimental infections, it was expected that all moribund animals would die within $24 \mathrm{~h}$ of observing clinical signs of disease (e.g. loose attachment to the substrate). Therefore, any moribund abalone observed were immediately sampled for examination by PCR and histology. For sampling, abalone were dissected to expose the pleuropedal ganglion and nerve cords. The neural tissue was removed and placed in either a tube on ice (for subsequent PCR) and transferred to $-20^{\circ} \mathrm{C}$ until DNA extraction; or, in $10 \%$ seawater formalin for a minimum of $24 \mathrm{~h}$ and then processed for histopathological analysis. Nucleic acid was extracted from frozen tissue samples and detected as described below.

\section{DNA extraction from abalone tissue}

Nucleic acid from AbHV-challenged and -unchallenged control abalone tissues (approximately $100 \mathrm{mg}$ of tissue including the target neural tissue surrounded by some muscle) was extracted (using Applied Biosystems Mag MAX Express 96 Viral Isolation Kit and the MagMAX Express-96 Magnetic Particle Processor) following the manufacturer's instructions, except that the final elution was made in $50 \mu l$. 


\section{Viral DNA detection}

Viral DNA was detected using qPCR (Corbeil et al. 2010) with the following modifications for the open reading frame (ORF)-66 qPCR (by homology to sequences of OsHV-1 in GenBank, ORF 66 is likely to encode a DNA primase small subunit): forward primer ORF66F1 (5'-TCC CGG ACA CCA GTA AGA AC-3'), reverse primer ORF66R1 (5'-CAA GGC TGC TAT GCG TAT GA-3'), and 6-carboxyfluorescein (FAM) and 6-carboxytetramethylrhodamine (TAMRA)labelled probe ORF66Prb1 (FAM-5'-TGG CCG TCG AGA TGT CCA TG-3'-TAMRA). The expected length of the amplicon is $146 \mathrm{bp}$. The thermal cycling conditions were $95^{\circ} \mathrm{C}$ for $59 \mathrm{~s}$, followed by 45 cycles of $95^{\circ} \mathrm{C}$ for $3 \mathrm{~s}$ and $60^{\circ} \mathrm{C}$ for $30 \mathrm{~s}$. $C_{\mathrm{T}}$ values $<38$ were considered positive for the presence of AbHV DNA.

\section{Preparation of plasmid DNA positive control}

In order to validate the results obtained with the experimental samples, the AbHV target amplicon (146 bp) was cloned into the pCR4 Blunt Topo vector (Invitrogen) according to the manufacturer's instructions. The recombinant plasmid from 1 clone was sequenced to confirm the presence of the amplicon. The plasmid, designated Topo-ORF66, was replicated in E. coli DH5 $\alpha$ and extracted using a QIAprep kit (Qiagen) according to the manufacturer's instructions. The concentration of the plasmid Topo-ORF66 was determined in triplicate by nanodrop spectrophotometry using a wavelength of $260 \mathrm{~nm}$ and extinction coefficient of $50 \mathrm{ng} \mathrm{cm} \mathrm{ml}^{-1}$ ). The supercoiled plasmid Topo-ORF66 was heated at $95^{\circ} \mathrm{C}$ for $5 \mathrm{~min}$ and put on ice for $5 \mathrm{~min}$ to separate the plasmid strands which facilitates the qPCR amplification process.

\section{Histology}

Formalin-fixed tissue sections containing the pleuropedal ganglion and nerve cords were prepared by routine histological procedures including dehydration through an alcohol series, paraffin embedding, sectioning (3-6 $\mu \mathrm{m})$ and staining with haematoxylin and eosin.

\section{Statistical analysis}

The log-rank (Mantel-Cox) test (GraphPad Prism ${ }^{\circledR}$ 5.02) was performed to compare the survival curves of abalone species challenged with the 5 AbHV strains.

\section{RESULTS}

\section{Cumulative mortality}

Morbidity and mortality occurred in all groups of abalone challenged with all AbHV variants during the trials (Fig. 1). No mortality occurred and no abnormal histology was observed among the negative control abalone.

\section{Comparative susceptibility of 3 abalone species to AbHV variants}

The log-rank (Mantel-Cox) test demonstrated no significant differences between abalone species challenged with AbHV variants within each challenge trial (results not shown) with the exception of Victorian blacklip abalone, which were more susceptible than the greenlip abalone upon challenge with AbHV Tas2 and Tas3 (Table 1).

\section{Histopathology/qPCR analysis}

All moribund abalone examined histologically demonstrated tissue lesions consistent with AVG (Hooper et al. 2007, Corbeil et al. 2012) (results not shown). No difference in histological lesions was observed between abalone species and virus variants.

All moribund abalone tested by the qPCR (Corbeil et al. 2010, OIE 2015) were positive for the presence of AbHV DNA. Amongst the abalone that survived the viral challenge, some were analysed by histology and tested by qPCR. In most cases, histological results were not definitive. However, 6 animals showed histological lesions typical of AVG, and amongst these, 4 tested positive by qPCR (Table 2). Overall, the mean $C_{\mathrm{T}}$ value of moribund abalone was much lower (higher viral load) than the mean $C_{\mathrm{T}}$ value of surviving abalone (Table 3).

\section{DISCUSSION}

The results show that greenlip, blacklip and brownlip abalone originating from the states of Victoria, Tasmania and SA, and the brownlip abalone from WA are susceptible to the $5 \mathrm{AbHV}$ variants tested (Vic1, Tas1, Tas2, Tas3 and Tas4). Greenlip from WA are susceptible to AbHV Tas3 and Tas4 but could not be tested with the variants Vic1, Tas1 and Tas2 due to difficulty in maintaining enough greenlip abalone 

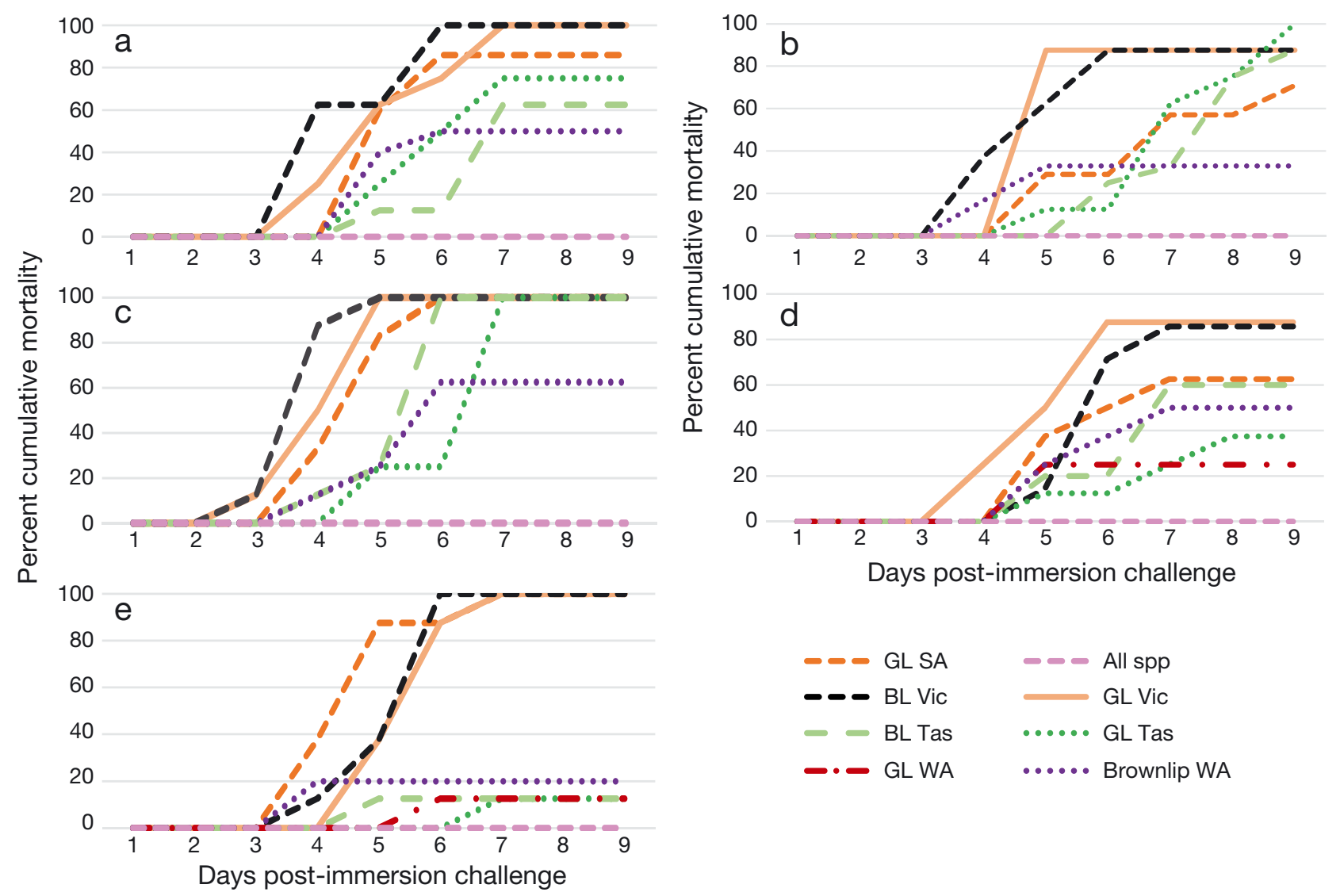

Fig. 1. Cumulative mortality curves for immersion trials of greenlip Haliotis laevigata (GL), blacklip H. rubra (BL) and brownlip H. conicopora abalone samples from populations originating from Victoria (Vic), Tasmania (Tas), South Australia (SA) and Western Australia (WA), following challenge with abalone herpesvirus (AbHV) genotypes (a) Vic1, (b) Tas1, (c) Tas2, (d) Tas3 and (e) Tas4. The difference between final cumulative mortality and $100 \%$ represents percentage survival. Note that curves from abalone originating from different states cannot be compared with each other

in healthy condition after transportation. Differences in pathogenicity between viral variants may exist; however, due to variation in viral growth and inability to titre infectious virus accurately, we could not establish differences in pathogenicity between the numerous challenge trials undertaken over a $2 \mathrm{yr}$ period. Indeed, because AbHV has not been successfully grown in cell culture, and molecular titration measures viral DNA present in suspension rather

Table 1. Log-rank (Mantel-Cox) test on Victorian greenlip abalone Haliotis laevigata and blacklip abalone $H$. rubra challenged with abalone herpesvirus (AbHV) genotypes Tas2 and Tas3. Results indicate that blacklip abalone were more susceptible than greenlip abalone upon challenge with Tas2 and Tas3

\begin{tabular}{|ccccc|}
\hline AbHV & $\chi^{2}$ & df & $p$ & $\begin{array}{c}\text { Curves significantly } \\
\text { different }(\mathrm{p}<0.05)\end{array}$ \\
\hline Tas2 & 9 & 1 & 0.0027 & Yes \\
Tas3 & 4.4 & 1 & 0.035 & Yes \\
\hline
\end{tabular}

than viable viral particles, precise comparative pathogenicity is not yet achievable.

Our results show that all abalone species tested are susceptible to the AbHV variants, although statistical analyses indicated differences in mortality between Victorian blacklip abalone and the Victorian greenlip upon AbHV Tas2 and Tas3 challenges with the same infectious water. Although both species showed identical final percent mortality, morbidity occurred faster in blacklip upon challenge with the Tas2 variant and faster in greenlip upon challenge with the Tas3 variant. A slight discrepancy in weight may have caused this difference and is a phenomenon we have noticed in previous studies (authors' pers. obs.).

In most surviving abalone in these trials, $C_{\mathrm{T}}$ values in the tissues were much higher (lower virus load) than in the abalone that succumbed to the infection. This suggests that some abalone were infected later than others in the immersion challenge, an observation supported by the fact that some of the surviving abalone that were positive by qPCR for viral DNA 
Table 2. Presence or absence of histological lesions and $C_{\mathrm{T}}$ values of experimental abalone Haliotis spp. surviving the virus challenge. A $C_{\mathrm{T}}$ value of $\geq 38$ is considered negative for the presence of viral DNA. AbHV: abalone herpesvirus, WA: Western Australia

\begin{tabular}{|lccccc|}
\hline Sample & $\begin{array}{c}\text { AbHV } \\
\text { variant }\end{array}$ & Species & Location & $\begin{array}{c}\text { Histological } \\
\text { lesion }\end{array}$ & $\begin{array}{c}\text { qPCR } \\
C_{\mathrm{T}} \text { value }\end{array}$ \\
\hline 1 & Tas3 & H. laevigata & Victoria & Absent & $\geq 40$ \\
2 & Tas4 & H. conicopora & WA & Present & 37.34 \\
3 & Tas1 & H. conicopora & WA & Present & $\geq 40$ \\
4 & Tas3 & H. conicopora & WA & Absent & $\geq 40$ \\
5 & Tas3 & H. conicopora & WA & Absent & 38.30 \\
6 & Tas3 & H. conicopora & WA & Present & 35.89 \\
7 & Vic1 & H. conicopora & WA & Present & 39 \\
8 & Vic1 & H. conicopora & WA & Present & 37.5 \\
9 & Vic1 & H. conicopora & WA & Absent & 39.5 \\
10 & Vic1 & H. conicopora & WA & Present & $\geq 40$ \\
11 & Vic1 & H. conicopora & WA & Absent & 37.99 \\
\hline
\end{tabular}

Table 3. Mean $C_{\mathrm{T}}$ values of experimental abalone Haliotis spp. surviving and succumbing to abalone herpesvirus (AbHV) challenge trials

\begin{tabular}{|lcc|}
\hline \multirow{2}{*}{ Abalone } & \multicolumn{2}{c|}{ qPCR $C_{\mathrm{T}}$ value } \\
sample & Mean & $\mathrm{SD}$ \\
\hline & & \\
\hline Sacrificed after trial & 34.96 & 4.81 \\
Harvested when morbid & 16.35 & 7.74 \\
\hline
\end{tabular}

also showed some histological lesions characteristic of AVG. The abalone may have become moribund within a few days had they not been sampled on Day 9 post-challenge. Further studies should determine whether some abalone can become sub-clinical carrier animals that could survive for an extended time (beyond the $9 \mathrm{~d}$ of this experiment).

Greenlip and brownlip abalone originating from WA were susceptible to AbHV Tas3 and Tas4 variants. In addition, the brownlip abalone were also susceptible to AbHV variants Vic1, Tas1 and Tas2.

Susceptibility of Tasmanian abalone to the viral variants originating from Tasmania raises a question. If Tasmanian variants are pathogenic in all abalone stocks including those from Tasmania, why has no outbreak of AVG been recorded in Tasmanian wild abalone populations (as has been seen in Victorian stocks)? Are the environmental conditions in the wild (stock density, marine currents, water temperature) so different from the experimental conditions that outbreaks did not occur? In that respect, Moore et al. (2000) demonstrated that for red abalone Haliotis rufescens, an increase in water temperature from 14.7 to $18.5^{\circ} \mathrm{C}$ enhances the severity of the pathogenic effects of rickettsia
'Candidatus Xenohaliotis californiensis,' the aetiological agent of withering syndrome. Similarly, Rogers-Bennett et al. (2010) showed that when red abalone infected by $X$. californiensis are exposed to warm water, they develop clinical signs of withering syndrome, and both males and females experience total reproductive failure. With regards to viral infection in molluscs, Pernet et al. (2015) showed that ostreid herpesvirus remains latent at low temperature but is reactivated and disease occurs in Pacific oysters when the water temperature increases to a threshold level.

In the case of AVG, perhaps the Tasmanian virus variants remain sub-clinical in Tasmanian wild abalone because environmental conditions (for example, water temperature) favour a latent or persistent infection. It would be interesting to hold a large number of wild Tasmanian abalone in the laboratory at slightly warmer temperatures than those recorded in Tasmanian waters, and look for evidence of reactivation of possible latent infections. A study by Corbeil et al. (2013) on heritability of resistance traits of greenlip abalone against AVG has shown that increased resistance to the disease varies according to the genotype of the species even without prior encounter with AbHV. Similarly, Pacific oysters are genetically diverse in terms of their susceptibility to ostreid herpesvirus infection (Dégremont 2013, Segarra et al. 2014, Dégremont et al. 2015). In addition, Friedman et al. (2014) showed that natural selection in black abalone can lead to natural recovery (from disease) of abalone populations over time under certain circumstances.

Regarding the biosecurity aspect, it remains crucial for Australian state government agencies to establish, and enforce, strict regulations that limit the transfer of potentially infected or carrier abalone stocks from one region to another in order to avoid further AVG outbreaks in Australian wild abalone.

Acknowledgements. We thank Ocean Grown Abalone Pty Ltd, Costal Seafarms Pty Ltd, Ocean Wave Seafoods Pty Ltd, Abtas Marketing Pty Ltd and 888 Abalone Pty Ltd for providing abalone species for the study. We also acknowledge the contributions made by staff of Craig Mostyn Group Jade Tiger abalone Pty Ltd, Indented Head, Victoria, for providing hybrid abalone. We thank Jean Payne and Jenni Harper from the histology laboratory at AAHL for processing fixed samples and Peter Mohr from AFDL CSIRO for technical 
assistance. This work was undertaken as part of FRDC Project No. 2013/001 (Aquatic Animal Health Subprogram: Determination of susceptibility of various abalone species and populations to the various known AbHV genotypes), and was supported by funding from the FRDC on behalf of the Australian Government.

\section{LITERATURE CITED}

Chang PH, Kuo ST, Lai SH, Yang HS, Ting YY, Hsu CL, Chen HC (2005) Herpes-like virus infection causing mortality of cultured abalone Haliotis diversicolor supertexta in Taiwan. Dis Aquat Org 65:23-27

Corbeil S, Colling A, Williams LM, Wong FYK and others (2010) Development and validation of a TaqMan ${ }^{\circledR}$ PCR assay for the Australian abalone herpes-like virus. Dis Aquat Org 92:1-10

Corbeil S, McColl KA, Williams LM, Ilhan M and others (2012) Abalone viral ganglioneuritis: establishment and use of an experimental immersion challenge system for the study of abalone herpes virus infections in Australian abalone. Virus Res 165:207-213

Corbeil S, Williams LM, Kube P, King H, Elliott N, Crane MStJ (2013) Aquatic Animal Health Subprogram: investigation into the genetic basis of resistance to infection by abalone herpes-like virus. Fisheries Research and Development Corporation Project No. 2011/003

Cowley JA, Corbeil S, Bulach D, Moody NJ and others (2012) Complete genome sequences of abalone herpes virus (AbHV) strains from Victoria and Tasmania provide insights into its origins and identity variations useful for epidemiology. In: Elliot $\mathrm{N}$ (ed) $8^{\text {th }}$ International Abalone Symposium, 6-11 May 2012, Hobart, Tasmania. International Abalone Society, p 86 (Abstract)

Crane MStJ, Corbeil S, Williams LM, McColl KA, Gannon V (2013) Evaluation of the abalone viral ganglioneuritis resistance among wild abalone populations along the Victorian coast of Australia. J Shellfish Res 32:67-72

Dégremont L (2013) Size and genotype affect resistance to mortality caused by OsHV-1 in Crassostrea gigas. Aquaculture 416-417:129-134

Dégremont L, Lamy JB, Pépin JF, Travers MA, Renault T (2015) New insight for the genetic evaluation of resistance to ostreid herpesvirus infection, a worldwide disease, in Crassostrea gigas. Plos ONE 10:e0127917

Ellard K, Baulch T, Andrewartha R (2012) Abalone viral ganglioneuritis: an update of descriptive epidemiology

Editorial responsibility: Mike Hine,

Fouras, France following investigations in Tasmania. In: Elliot $\mathrm{N}$ (ed) $8^{\text {th }}$ International Abalone Symposium, 6-11 May 2012, Hobart, Tasmania. International Abalone Society, p 85 (Abstract)

Friedman CS, Wight N, Crosson LM and others (2014) Reduced disease in black abalone following mass mortality: phage therapy and natural selection. Front Microbiol $5: 78$

> Hooper C, Hardy-Smith P, Handlinger J (2007) Ganglioneuritis causing high mortalities in farmed Australian abalone (Haliotis laevigata and Haliotis rubra). Aust Vet J 85:188-193

Moore JD, Robbins TT, Friedman CS (2000) Withering syndrome in farmed red abalone Haliotis rufescens: thermal induction and association with a gastrointestinal Rickettsiales-like prokaryote. J Aquat Anim Health 12:26-34

OIE (World Organisation for Animal Health) (2015) Manual of diagnostic tests for aquatic animals. OIE, Paris. Available at www.oie.int/en/international-standard-setting/ aquatic-manual/access-online/

Pernet F, Tamayo D, Petton B (2015) Influence of low temperatures on the survival of the Pacific oyster (Crassostrea gigas) infected with ostreid herpes virus type 1. Aquaculture 445:57-62

Rogers-Bennett L, Dondanville RF, Moore JD, Vilchis LI (2010) Response of red abalone reproduction to warm water, starvation, and disease stressors: implications of ocean warming. J Shellfish Res 29:599-611

Savin KW, Cocks BG, Wong F, Sawbridge T, Cogan N, Savage $\mathrm{D}$, Warner $\mathrm{S}$ (2010) A neurotropic herpesvirus infecting the gastropod, abalone, shares ancestry with oyster herpesvirus and a herpesvirus associated with the amphioxus genome. Virol J 7:308

Segarra A, Mauduit F, Faury N, Trancart S and others (2014) Dual transcriptomics of virus-host interactions: comparing two Pacific oyster families presenting contrasted susceptibility to ostreid herpesvirus 1. BMC Genomics 15: 580

Tan J, Lancaster M, Hyatt A, van Driel R, Wong F, Warner S (2008) Purification of a herpes-like virus from abalone (Haliotis spp.) with ganglioneuritis and detection by transmission electron microscopy. J Virol Methods 149: 338-341

Wang JY, Guo ZX, Feng J, Liu GF, Xu LW, Chen BS, Pan JP (2004) Virus infection in cultured abalone, Haliotis diversicolor Reeve in Guandong province, China. J Shellfish Res 23:1163-1168

Submitted: December 15, 2015; Accepted: March 2, 2016 Proofs received from author(s): April 19, 2016 